\title{
WestVirginiaUniversity
}

THE RESEARCH REPOSITORY @ WVU

Graduate Theses, Dissertations, and Problem Reports

2001

\section{Factors contributing to college freshmen placed on academic probation}

Lee Ann Vecellio

West Virginia University

Follow this and additional works at: https://researchrepository.wvu.edu/etd

\section{Recommended Citation}

Vecellio, Lee Ann, "Factors contributing to college freshmen placed on academic probation" (2001). Graduate Theses, Dissertations, and Problem Reports. 833.

https://researchrepository.wvu.edu/etd/833

This Thesis is protected by copyright and/or related rights. It has been brought to you by the The Research Repository @ WVU with permission from the rights-holder(s). You are free to use this Thesis in any way that is permitted by the copyright and related rights legislation that applies to your use. For other uses you must obtain permission from the rights-holder(s) directly, unless additional rights are indicated by a Creative Commons license in the record and/ or on the work itself. This Thesis has been accepted for inclusion in WVU Graduate Theses, Dissertations, and Problem Reports collection by an authorized administrator of The Research Repository @ WVU. For more information, please contact researchrepository@mail.wvu.edu. 


\title{
Factors Contributing to College Freshmen Placed on Academic Probation
}

\author{
Lee Ann Vecellio \\ Thesis submitted to the \\ College of Human Resources and Education \\ at West Virginia University \\ in partial fulfillment of the requirements \\ for the degree of
}

\author{
Master of Arts \\ in \\ Educational Psychology \\ Floyd L. Stead, Ed.D., Chair \\ Andrew D. Katayama, Ph.D. \\ Patricia A. Haught, Ed.D. \\ Ernest R. Goeres, Ph.D. \\ Department of Educational Psychology \\ Morgantown, West Virginia
}

2001

Keywords: freshmen, academic probation, factors 


\section{Abstract \\ Factors Contributing to College Freshmen Placed on Academic Probation \\ Lee Ann Vecellio}

The responses of college freshmen placed on academic probation to a survey examining the factors leading to their poor academic performance were studied to ascertain the perceived problem areas. One hundred and seventy-two college freshmen selected factors concerning motivation, time management, social, and financial components, which they believed contributed to their poor academic performance during their freshman year. For males, inadequate balance between time and other activities was perceived as the number one factor contributing to their demise. On the other hand, females selected lack of academic motivation as their number one factor. Interestingly, these factors were reversed when identifying the second most contributing factor. The factors selected to be the main problem areas in a student's academic performance were analyzed comparing gender and major. No significant differences were found. 


\section{ACKNOWLEDGMENTS}

I would like to thank my family and friends for all the love and encouragement they gave me. I also would like to extend my gratitude to the Educational Psychology Department for there guidance and support, especially to Dr. Larry Stead, Dr. Patricia Haught, Dr. Andrew Katayama, Dr. Ernest Goeres, and Ann Crabtree, who had faith in me when I had little left in myself. 
TABLE OF CONTENTS

ABSTRACT

ACKNOWLEDGEMENTS. iii

TABLE OF CONTENTS..................................................................... iv

LIST OF TABLES AND FIGURES............................................... v

\section{CHAPTER 1}

INTRODUCTION

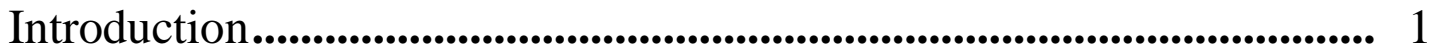

Research Questions................................................................................................. 2

\section{CHAPTER 2}

REVIEW OF LITERATURE

The Support Network........................................................................... 3

The Institutional Environment ............................................................... 6

Time Management ................................................................................ 7

Gender Differences ............................................................................ 8

Summary …........................................................................................................... 9

\section{CHAPTER 3}

METHODOLOGY

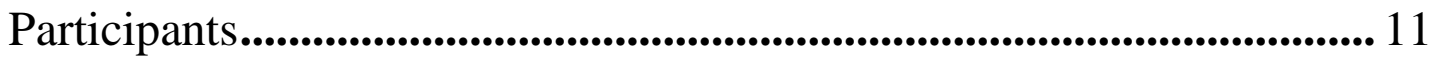

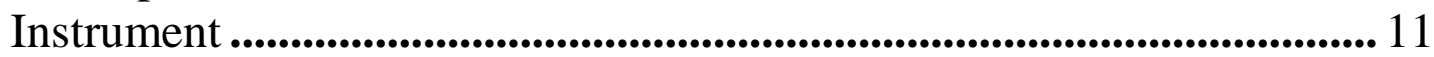

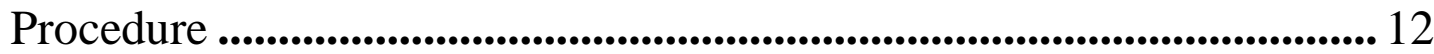

Design and Data Analysis...................................................................... 13 
CHAPTER 4

\section{RESULTS}

Group Results 14

Male versus Female ........................................................................... 16

Results by Major ........................................................................................................... 17

\section{CHAPTER 5}

\section{DISCUSSION}

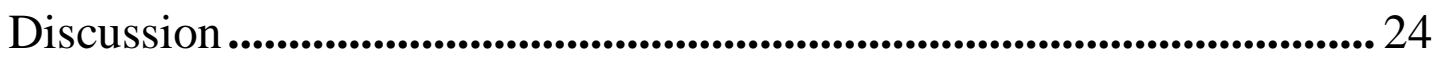

Future Research .......................................................................................................... 27

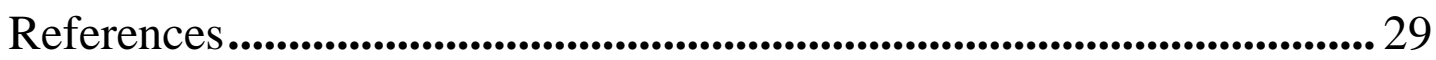

Appendix A............................................................................................................ 32

Appendix B .................................................................................................................... 33

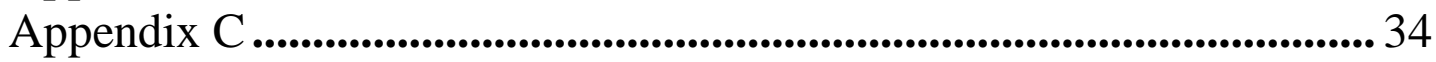

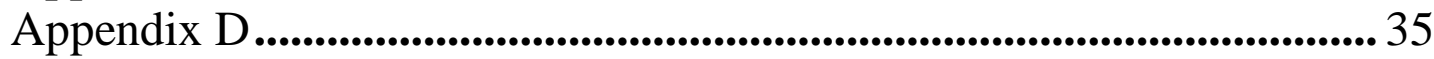

Appendix E .......................................................................................................... 36

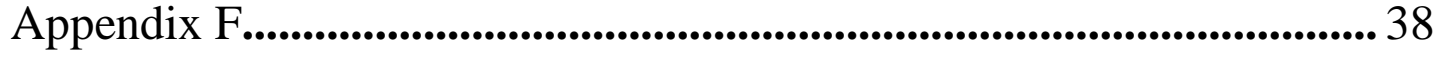




\section{LIST OF TABLES, CHARTS, AND APPENDICES}

Table 1: Frequency distribution of factors contributing to poor academic performance for the group ......................................... 15

Table 2: Frequency distribution of factors contributing to poor academic performance by gender ............................................ 20

Table 3: Factors selected by males and females in general studies........ 21

Table 4: Factors selected by males and females in pre-business and economics .................................................................................. 22

Table 5: Factors selected by males and females in pre-biology .............. 23

Table 6: Factors selected by males and females in pre-psychology...... 24

Appendix A: Pie chart of distribution of majors ....................................... 32

Appendix B: Survey of factors contributing to poor academic performance ......................................................................... 33

Appendix C: List of factors for "other" category..................................... 34

Appendix D: List of factors for difficulty learning specific course material ................................................................................... 35

Appendix E: Chi-square analysis results (Table 7) ................................... 36

Appendix F: Crosstabulation of gender and major code........................... 38 


\section{CHAPTER ONE}

\section{Introduction}

Student academic performance is one of the leading concerns at colleges and universities nationwide. This is not an issue to be taken lightly with the dropout rate climbing close to $30 \%$, most of which occurs during the freshman year (ACTNews, 2000). In the past two decades, colleges and universities have attempted to make higher education more accessible to diverse groups, even as the pool of traditionally academically prepared freshmen have decreased (Dey, Astin, \& Korn, 1991). Due to these social pressures of keeping enrollment up, increasing needs for generating revenue, and other factors, most institutions are admitting students who not only are academically ill-prepared but also may lack the self-regulatory skills necessary for successful adjustment to campus life. Remedial intervention programs at Carnegie Mellon aim to help students with learning difficulties adopt attritional principles for improving performance after academic failure. Many programs have even focused on grouping the probationary students with on-campus living arrangements to facilitate support networks to minimize the stress students may feel from their lack of academic success (Wratcher, 1991).

Problems vary widely in the scope of how to measure a student's success or failure. The factors, which were the primary cause of probation or suspension, were also equally difficult to measure and interpret. The purpose of this study was to identify possible factors that may prevent some students from completing their freshman year. Many studies exist showing the relationship between academic performance and 
retention. However, there are only a few references to the factors that relate to or may be thought to cause poor academic performance. This study sought to determine the factors perceived by freshman actually placed on academic probation as contributing to the cause resulting in their academic probation.

\section{Research Questions}

1. What are the factors contributing to college freshmen being placed on academic probation?

2. Do women and men significantly differ on student-perceived factors which contribute to poor academic performance?

3. Is there a significant difference between major and total factors selected by students? 


\section{CHAPTER TWO Literature Review}

Many researchers have examined the academic performance of first time college freshmen to see if they are adequately prepared for college level coursework. This area has received national attention within universities and colleges. Some institutions are now calling their advising centers "the advising and retention department" partly due to the ever growing numbers of dropouts and also the academically poor performance of students (Braunstein \& McGrath, 1997). Academic performance has been a focal point of many educators and committees over the past ten years.

\section{$\underline{\text { The Support Network }}$}

Why do some students excel from the start of their college careers and others struggle? Some believe it is due to poor time management, academic unpreparedness, and lack of direction (Wratcher, 1991). Others believe it is due to poor support networks of the individuals. Persisters in college established a significant personal tie with someone on campus, faculty, or student. The degree and quality of the interactions with other members of the institution proved to be a critical element in the process of student persistence. While in contrast, absence of sufficient contact with other members of the institution proves to be the single most important predictor of eventual departure even after taking account of the independent effects of background, personality, and academic performance. (Pascarella \& Terenzini, 1979). Tinto's $(1975,1987)$ model on student integration shows students who become integrated into the social and academic systems of their college are most likely to maintain a strong commitment to attaining a college 
degree. Tinto argues that a college student's successful completion of the stages of separation, transition and incorporation are most important early in a student's college career, and research supports this argument. A student's social support can be a crucial component to their advancement in college. Studies have found students with more secure attachments are more likely to persist in college and experience less school-related stress. A large amount of psychological benefits can be gained by receiving support from others. Perrine (2001) notes there are two equally important components: (a) the social support is the objective availability of others who are willing to help in times of stress and (b) social support is a perception. When others are experiencing similar stressors, there is a limit to the extent to which it is helpful. The group may experience the feeling of a "collective sinking ship" which can harm motivation. Students grouped in intensive study programs after a previous year of poor academic performance experience a certain amount of isolation partly due to the structured weekly schedule they are required to maintain (Berry, Pike, \& Schroeder, 1997).

Students may find themselves at a loss as they move from a teacher-directed high school environment that is highly structured to a student-directed college environment that requires them to impose a structure of their own on the academic experience. The school day is no longer devoted to classes from morning to afternoon; no longer does the teacher emphasize what is "the important information" in the textbook nor what material "will be covered on the test" and no longer does the teacher come to the students when they are showing difficulty in understanding the material (Wratcher, 1991). There is an initial assumption that college freshmen are expected to be self-directed. Karabenick and 
Knapp (1988), in their study on college students' "help-seeking behavior," found that over eighty percent of freshmen and sophomores (550 of 612) never accessed university support for academic assistance although available to them.

At the time of entering into a new academic environment students are confronted with separation issues, such as separation from their parents and familiar peer group, and placed in an environment, for most teens that has generally been secure and comfortable for the past eighteen years. Kenny (1987) found that most college freshmen remain close with their parents and continue to seek emotional support from them, but feel ambivalent or embarrassed by the relationship. Though most freshmen look forward to autonomy, most are still financially dependent on their parents, while being responsible for aspects of their daily routines, eating properly, managing money, and laundry. In this new environment freshmen encounter people of many different backgrounds, beliefs, and values that they may be living with. With these different backgrounds come varying study habits, eating and sleeping patterns and social networks which can place added stress on the student before classes have yet to start. This leaves the student with limited outlets for personal space, uninterrupted sleep, and a quiet studying environment. During all of this, developing a sense of sexual identity and interpersonal relationships appears to take precedence over all else. Many of these students' problem-solving and decisionmaking skills which are needed to address these issues are not yet fully developed (Wratcher, 1991). 


\section{The Institutional Environment}

The process of choosing a college involves the formation of a set of expectations pertaining to the character of the institution. The student then selects a college or university on the basis that those institiutions has those characteristics. Upcraft and Gardner (1989) suggest that an institution's environment or ecology is a powerful determinant of freshmen success. This idea from the ecological standpoint predicts that student development may or may not occur depending on the "fit" of the student and the institutional environment. If the shift from high school to college is favorable, then the growth and academic prosperity of the student should occur. Ecological determinants of right "fit" can include campus location, location of dormitory to classes, and the student body of the university. The Fund for the Improvement of Postsecondary Education (FISPE) has designated college match as a high priority item in its research endeavors (Brazziel, 1982). Many dormitories are located within reasonable walking distance to most university buildings; however, lack of attendance in classes still remains a leading factor to students being placed on academic probation. Professors have established attendance policies in courses in an effort to increase academic performance and decrease failing grades. Academic advisors at the time of registration discuss the importance of having a balanced schedule across the week, as well as the students' orientation to morning, afternoon, or evening classes to design a schedule geared toward the student's individual needs. Many of the students are still able to find an adequate schedule per semester/quarter. Unfortunately they do not always take courses required for their major going against the advice of faculty which creates more stress for the student. 
Declaring a major is not an easy task for the vast majority of college freshmen. Many questions arise when determining a major for a new student: What subject matter do I enjoy, What can I do with a degree in ....?, What could I see myself doing long term?, or What is a good field of study that will give me enjoyment and a comfortable living?. These questions arise due to the lack of exposure to subject matter in high schools that is required at universities. This leaves the student wondering what the major entails and if he would enjoy the subject matter he would be studying. Inaccurate expectations can have a substantial and lasting effect in terms of departure (Tinto, 1987). Koestner and Senecal (1995) found students who procrastinate and do not research the major that would best fit their capabilities tend to make rush decisions. This causes them to struggle with course material and impedes their efforts to succeed academically. Others have reported that some students don't really know what they're working toward when they come to college, so they flounder, become frustrated, and leave.

\section{$\underline{\text { Time Management }}$}

It is difficult to think of someone who never procrastinates. Procrastination involves knowing that one is supposed to be doing an activity (such as college algebra problems), and perhaps even wanting to do so, yet failing to be motivated enough to perform the activity within the desired amount of time. Procrastination typically involves delaying the start of a task until one experiences a certain level of stress about not having performed the activity earlier (Koestner \& Senecal, 1995). Most individuals have a theory as to why they procrastinate. Empirical research supports the notion that academic procrastination is a motivational problem involving more than poor time management 
skills or trait laziness. Nationally, studies (Koestner \& Senecal, 1995) have found 95\% of all American college students procrastinate. Solomon and Rothblum (1984) showed that although students attributed many different reasons for their procrastination, the majority of the reasons were directly related to fear of failure (e.g., performance anxiety, perfectionism, and lack of self-confidence). In addition, research on academic procrastination has consistently discovered that students who regularly procrastinate score significantly higher than other students on trait anxiety and depression, and significantly lower on self-esteem (Koestner \& Senecal, 1995; Solomon \& Rothblum, 1984). Anxiety, depression, and low self-esteem can be conceptualized as trait factors related to a fear of failure.

\section{$\underline{\text { Gender Differences }}$}

Astin, Hemond, and Richardson (1982) observed that

Female departure from a university differs from male departure in the form their leaving takes. As a group females are more likely to depart voluntarily than are males, wheras males are more likely to stay in college until forced to leave for academic reasons. Presumably the press for occupational attainment remains stronger among males than it does among females. Not only are females less likely to be enrolled in occupationspecific programs of study, they are also less likely to plan to enter occupations after college (p. 74).

Compared to men, women have generally been reported as being more intrinsically motivated than men and less externally regulated and motivated with regard to academic activities (Vallerand \& Bissonnette, 1992), but most would think that women 
would procrastinate less. Koestner and Senecal (1995) reported that women procrastinated less than men. Females displayed a heightened achievement, intellectual, and academic outcomes earlier in their academic careers. Females also experienced more nurturance and support from parents early in their academic careers (Biller, 1993). Much of the facilities on high school campuses are dominated by female teachers who act as positive and nurturing role models during early childhood, creating an over representation for female students. Most universities have male and female faculty members with differing teaching styles, placing students at a disadvantage that grew accustomed to the female pattern of teaching. This representation of male to female educators is more evenly distributed at universities. Research has shown male college students place more emphasis on their grades as a predictor of achievement than do female students (Hickman, Toews, \& Andrews, 2001). The factors contributing most to males and females having a successful college career are the presence of an adequate support network, time management skills, and class attendance. These factors appear to also be primary contributors for both males and females.

\section{$\underline{\text { Summary }}$}

Many studies have looked at student retention rates, support networks, institutional environment, and other possible contributing factors but less research has been conducted on the factors perceived by the students themselves as contributing to their academic distress. Even less research has attempted to identify the issues contributing to academic probation. Academic adjustment concerns focus on student learning skills that are needed for academic achievement. Some of the most frequently 
occurring factors are time management, students' preparatory knowledge base, and other learning skills, such as listening, note-taking, test-taking skills, and critical thinking (Wratcher, 1991). By understanding what these factors are, educators can then handle the social and academic adjustments of first time college students. Using the factors identified in the present survey, educational workshops and intervention programs can be better geared toward strengthening student weaknesses. This study sought to identify student-perceived factors that remain an ongoing problem for this university as well as many other colleges and universities nationwide and possibly provide solutions for redesigning intervention programs to target these issues. 


\section{CHAPTER THREE \\ Methodology}

\section{$\underline{\text { Participants }}$}

For the purpose of this study, first time college freshmen placed on academic probation after receiving below a 2.0 overall GPA upon completion of the fall semester 1999 served as participants. Within the entire university there were a total of 962 freshmen placed on academic probation. The Academic Advising Center where I was employed as an advisor had 386 students placed on academic probation during the fall 1999 semester. The other 576 students were advised directly through their departments. Participation in this study was voluntary, and 172 out of 386 of these students $(44.6 \%)$ volunteered. All 172 students were enrolled full-time in the spring 2000 semester. Sixtyfive students were enrolled as general studies majors, thirty-five were enrolled as prebusiness and economics majors, twelve were pre-psychology, and ten were pre-biology majors (see Appendix A). The other fifty represented various pre-arts and science majors (e.g., journalism, nursing, physical therapy, and medical technology). There were 88 male and 84 female participants.

\section{$\underline{\text { Instrument }}$}

The instrument used for the study was a survey compiled from Wayne State University's Excell Program by the West Virginia University Academic Advising Center to ascertain problem areas for students placed on probation in the spring of 2000. Two surveys were combined from Wayne State to form the survey used for the purposes of this study. The surveys used were a re-instatement application and the university 
advising center academic survey. The survey was modified to address the social, financial, and academic environments of the student. There were 25 factors on the survey, two of which were open-ended to allow for possible other factors overlooked by the survey (see Appendix B). The number of failing mid-term reports received by the students was also included to identify the students who were at risk of receiving below a 2.0 GPA for a second consecutive semester and at risk of suspension from the university. One open-ended question was included in the survey to identify specific courses that were perceived as problem areas for the students. A second open-ended question was added at the end of the factor list to provide an area for the students to identify factors not present on the survey. Attempts to obtain reliability and validity coefficients on the instrument were unsuccessful. However, it should be pointed out that the students that I personally advised had no difficulty utilizing the instrument for its intended purpose.

\section{Procedure}

The survey was administered in the spring 2000 to the students while they were completing their fall 2001 registration. The normal registration appointments were 30 minutes per student, but for the purposes of registration and administering the survey, probationary students were given 45-minute appointments with their advisors. Though the survey was optional, students were strongly encouraged to complete it for mutual benefit of the student and the advising center. There were no consequences for the student not completing the survey. The students were asked if they would complete a survey of possible factors leading to their probation. If they agreed, they received the survey in their advisor's office and were given five to ten minutes to complete the survey. 
Upon completion of the survey, the advisor then went over the factors the student selected. This was done in an attempt to give the student some possible resources such as on-campus tutoring facilities and counseling telephone numbers, and possible literature to utilize for improving the factors that were identified by the student to be problem areas. The original survey was then placed in the student's file and stored in the record department in the West Virginia University Academic Advising Center.

\section{Design and Data Analysis}

A single group, descriptive survey study was conducted to identify the major factors contributing to academic probation for college freshmen. Comparisons of contributing factors were made between those selected by males and those selected by females. Comparisons of contributing factors were also made based on student majors. Chi square analyses were conducted to ascertain if any statistically significant differences were present for major and gender. 


\section{CHAPTER FOUR}

\section{Results}

\section{Group Results}

For this study, 172 freshmen that began in the 2000 fall semester and were placed on probation in the spring 2001 volunteered to participate. A frequency table for the 25 (A-Y) factors was constructed (see Table 1). The factors having the largest contribution on student achievement for the group (all 172 participated) were inadequate balance between other activities and class work $54.1 \%(\underline{\mathrm{n}}=93)$; lack of academic motivation $48.8 \%(\underline{\mathrm{n}}=84)$; setting priorities $48.3 \%(\underline{\mathrm{n}}=83)$; and poor test-taking $47.7 \%(\underline{\mathrm{n}}=82)$. The least likely factors were difficulty in decision making, use of alcohol and/or drugs, depression, loneliness, and inadequate family support. Students selected the factors contributing most to their probation. Six factors tied for their placement in the frequency of responses. Poor reading skills and experiencing test anxiety frequency of response was eleventh, money management and health frequency of response was sixteenth, and difficulty in decision making and poor writing skills frequency of response was twentieth in their placement. 


\section{Table 1}

\section{Frequency Distribution of Factors Contributing to Poor Academic Performance}

$$
(\mathrm{N}=172)
$$

\begin{tabular}{|c|c|c|c|}
\hline Factor & \#Responses & $\%$ Responses & Freq.Occur. \\
\hline $\begin{array}{c}\text { A= Inadequate balance between } \\
\text { other activities class work }\end{array}$ & 93 & 54.1 & 1 \\
\hline $\mathbf{G}=$ Lack of academic motivation & 84 & 48.8 & 2 \\
\hline M= Setting priorities & 83 & 48.3 & 3 \\
\hline $\mathrm{C}=$ Poor test-taking & 82 & 47.7 & 4 \\
\hline $\begin{array}{l}\mathrm{L}=\text { Difficulty in adjusting to a college } \\
\text { routine }\end{array}$ & 77 & 44.8 & 5 \\
\hline$K=$ Not attending class & 74 & 43.0 & 6 \\
\hline $\mathbf{R}=$ Poor concentration & 66 & 38.4 & 7 \\
\hline$X=$ Lack of interest $/$ boredom & 54 & 31.4 & 8 \\
\hline I= Too much stress & 49 & 28.5 & 9 \\
\hline $\mathbf{H}=$ Lack of career direction & 48 & 23.3 & 10 \\
\hline $\mathrm{D}=$ Poor reading skills & 38 & 22.1 & $11 *$ \\
\hline$F=$ Experiencing test anxiety & 38 & 22.1 & $11 *$ \\
\hline $\begin{array}{c}\mathbf{T}=\text { Difficulty learning specific course } \\
\text { material }\end{array}$ & 30 & 17.4 & 13 \\
\hline $\mathrm{N}=$ Problems with roommate & 27 & 15.7 & 14 \\
\hline$Y=$ Other & 24 & 14.0 & 15 \\
\hline $\mathrm{J}=$ Money management & 23 & 13.4 & $16^{*}$ \\
\hline$P=$ Health & 23 & 13.4 & $16^{*}$ \\
\hline$B=$ Poor note-taking skills & 21 & 12.2 & 18 \\
\hline $\mathrm{O}=$ Interpersonal relationships & 16 & 9.3 & 19 \\
\hline$Q=$ Difficulty in decision making & 14 & 8.1 & $20 *$ \\
\hline$E=$ Poor writing skills & 14 & 8.1 & $20 *$ \\
\hline$V=$ Use of alcohol and $/$ or drugs & 8 & 4.7 & 22 \\
\hline $\mathbf{U}=$ Depression & 7 & 4.1 & 23 \\
\hline $\mathbf{S}=$ Loneliness & 5 & 2.9 & 24 \\
\hline $\begin{array}{c}\mathrm{W}=\text { Inadequate family and friend } \\
\text { support }\end{array}$ & 4 & 2.3 & 25 \\
\hline
\end{tabular}

* Indicates ties in rank of factors. 


\section{Male versus Female Results}

Factors related to gender differences are summarized in Table 2. Inadequate balance between other activities and class work was the most frequently occurring factor for male students and the second leading factor for females. Lack of academic motivation was the leading factor for female students. Three factors tied in the frequency of response between gender: poor reading skills, lack of interest/boredom, and problems with roommates. For the males, lack of academic motivation and poor test taking; experiencing test anxiety and problems with roommate; poor writing skills and interpersonal relationships and other category were viewed to be equally important among the frequency of responses. For the purposes of the frequency of responses for both males and females the fourth and fifth leading factors were equally viewed a contributors. Poor test taking and lack of academic motivation were selected as frequently $(\underline{n}=39)$. Experiencing test anxiety and problems with roommates were selected equally $(\underline{n}=13)$. Lower frequency of responses are listed in Table 2. For the female category, the factors that tied were not attending class and poor concentration, difficulty learning specific course material and poor writing skills, poor note-taking skills and interpersonal relationships, other and depression, and use of alcohol and / or drugs and inadequate family and friend support. Not attending class and poor concentration $(\underline{n}=39)$ was selected as being the fourth most selected, difficulty learning specific course material and poor writing skills were tied $(\underline{\mathrm{n}}=15)$, and poor note-taking skills and interpersonal relationships were also tied $(\underline{\mathrm{n}}=7)$. See Table 2 for lower ranks. The top thirteen factors between gender were consistently 
viewed as the largest contribution to the student's academic performance. The bottom twelve factors had more variation in the frequency of responses between major and gender and are listed in Tables 2 through 6.

\section{$\underline{\text { Results by Major }}$}

General studies was the largest portion of the sample size $(\underline{n}=65)$. Prebusiness and economics was the second largest group $(\underline{\mathrm{n}}=37)$. The choices were consistent with the overall choices of the sample group and are listed in Tables 3 through 6. Males in general studies $(\underline{n}=36)$ chose inadequate balance between other activities and class work for their poor performance (see Table 3$)$. Females in general studies $(\underline{\mathrm{n}}=$ 29) selected lack of academic motivation as the leading factor for their inadequate performance. For pre-business and economics $(\underline{\mathrm{n}}=37)$ and pre-biology $(\underline{\mathrm{n}}=12)$ the choices were somewhat different from the other majors (see Tables $4 \& 5$ ). For males, poor concentration was a primary component of their unsatisfactory performance. Female pre-business and economics majors $(\underline{n}=13)$ was the only group who chose money management as a leading cause of their under achievement. The other commonality was among female pre-psychology $(\underline{\mathrm{n}}=7)$ and pre-business and economics majors selection of too much stress as a component. As reported in Table 4, prebusiness and economics males did not find money management to be an important determinant of their probation. The selection of factors for pre-biology students was consistent with those of the overall group (see Table 5). Within this category the mentioned laziness, death in family, homesickness, oversleeping as possible contributors (see Appendix D for more results). Males and females in pre-biology selected 
inadequate balance between other activities and class work to be the reason for their poor performance. Males in pre-psychology were the only group, which viewed other as a contributing factor in their academic performance (see Table 6). Males in prepsychology found inadequate balance between other activities and class work and setting priorities as non-significant in their cause for probation. There were a variety of responses to the two factors that were open-ended questions: difficulty learning course material and other. Many students listed introductory level courses from arts and sciences as being difficult. The classes included chemistry, biology, psychology, and mathematics (see Appendices C \& D).

With the alpha level of .05, Chi-square analyses were computed on the comparison of gender, major, and total number of factors selected by a student (see Table 7, Appendix E). No significant relationships were found among any variables (all $\mathrm{p}>$ $.05)$. There was a significant difference between the observed frequency of major and gender. 
Table 2

Frequency Distribution of Factors Selected by Gender $(N=172)$

\begin{tabular}{|c|c|c|c|c|c|c|}
\hline Factors & $\begin{array}{l}\text { Male } \\
\text { Rank }\end{array}$ & $\begin{array}{l}\text { Female } \\
\text { Rank }\end{array}$ & $\begin{array}{l}\text { Male } \\
\text { Total } \\
\underline{\mathbf{n}}=\mathbf{8 8}\end{array}$ & $\begin{array}{c}\text { Female } \\
\text { Total } \\
\underline{\mathbf{n}=84}\end{array}$ & $\begin{array}{c}\text { Male } \\
\%\end{array}$ & $\begin{array}{c}\text { Female } \\
\%\end{array}$ \\
\hline $\begin{array}{l}\text { Inadequate balance between } \\
\text { other activities and class } \\
\text { work }\end{array}$ & 1 & 2 & 49 & 44 & 55.6 & 52.3 \\
\hline Setting priorities & 2 & 7 & 47 & 36 & 53.4 & 42.8 \\
\hline $\begin{array}{l}\text { Difficulty in adjusting to } \\
\text { college routine }\end{array}$ & 3 & 6 & 40 & 37 & 53.4 & 44.0 \\
\hline Lack of academic motivation & $4 *$ & 1 & 39 & 45 & 44.3 & 53.5 \\
\hline Poor test-taking skills & $4 *$ & 3 & 39 & 43 & 44.3 & 51.1 \\
\hline Not attending classes & 6 & $4 *$ & 35 & 39 & 39.7 & 46.4 \\
\hline Poor concentration & 7 & $4 *$ & 27 & 39 & 30.6 & 46.4 \\
\hline Lack of interest/boredom & 8 & 8 & 26 & 28 & 29.5 & 33.3 \\
\hline Lack of career direction & 9 & 12 & 24 & 16 & 27.2 & 19.0 \\
\hline Too much stress & 10 & 9 & 23 & 26 & 26.1 & 30.9 \\
\hline Poor reading skills & 11 & 11 & 20 & 18 & 22.7 & 21.4 \\
\hline $\begin{array}{l}\text { Difficulty learning specific } \\
\text { course material }\end{array}$ & 12 & $13 *$ & 15 & 15 & 17.0 & $\mathbf{1 7 . 8}$ \\
\hline Poor note-taking skills & 13 & $20 *$ & 14 & 7 & 15.9 & 8.3 \\
\hline Experiencing test anxiety & $14^{*}$ & 10 & 13 & 25 & 14.7 & 29.7 \\
\hline Problems with roommates & $14^{*}$ & 15 & 13 & 14 & 14.7 & 16.6 \\
\hline Money management & 16 & 17 & 12 & 11 & 13.6 & 13.3 \\
\hline Health & 17 & 16 & 11 & 12 & 12.5 & 14.2 \\
\hline Poor writing skills & $18 *$ & $13 *$ & 9 & 15 & 10.2 & 17.8 \\
\hline Interpersonal relationships & $18 *$ & $20 *$ & 9 & 7 & 10.2 & 8.3 \\
\hline Other & $18 *$ & $22 *$ & 9 & 5 & 10.2 & 5.9 \\
\hline Use of alcohol and/or drugs & 21 & $24 *$ & 6 & 2 & 6.8 & 2.3 \\
\hline Difficulty in decision making & 22 & 18 & 5 & 9 & 5.6 & 10.7 \\
\hline Depression & $23 *$ & $22 *$ & 2 & 5 & 2.2 & 5.9 \\
\hline $\begin{array}{l}\text { Inadequate family and } \\
\text { friend support }\end{array}$ & $23^{*}$ & $24 *$ & 2 & 2 & 2.2 & 2.3 \\
\hline Loneliness & 25 & 23 & 1 & 4 & 1.1 & 4.7 \\
\hline
\end{tabular}


TABLE 3

\section{Factors Selected by Males and Females in General Studies}

\begin{tabular}{|l|c|c|}
\hline \multicolumn{1}{|c|}{ FACTORS } & MALE RANK & FEMALE RANK \\
\hline $\begin{array}{l}\text { Inadequate balance between other } \\
\text { activities and class work(A) }\end{array}$ & 1 & 5 \\
\hline $\begin{array}{l}\text { Difficulty in adjusting to a college } \\
\text { routine(L) }\end{array}$ & 1 & 7 \\
\hline Setting priorities(M) & 1 & 3 \\
\hline Poor test-taking skills(C) & 4 & 1 \\
\hline Lack of academic motivation(G) & 4 & 9 \\
\hline Lack of career direction(H) & 4 & 3 \\
\hline Not attending classes(K) & 7 & 10 \\
\hline Poor reading skills(D) & 8 & 8 \\
\hline Lack of interest/boredom $(\mathrm{X})$ & 9 & 6 \\
\hline Poor concentration(R) & 10 & \\
\hline
\end{tabular}

\begin{tabular}{|c|l|}
\hline \multicolumn{1}{|c|}{} & $\begin{array}{l}\text { Inadequate balance between other activities and class } \\
\text { work (19) } \\
\text { Difficulty in adjusting to a college routine (19) } \\
\text { Setting priorities (19) } \\
\text { Poor test taking skills (15) } \\
\text { Lack of academic motivation (15) } \\
\text { Lack of career direction (15) } \\
\text { Not attending classes (14) } \\
\text { Poor reading skills (12) } \\
\text { Lack of interest / boredom (11) } \\
\text { Poor concentration (10) }\end{array}$ \\
\hline
\end{tabular}

\begin{tabular}{|c|l|}
\hline \begin{tabular}{|l|} 
FEMALE \\
$\underline{\mathrm{n}}=29$ \\
$44.6 \%$
\end{tabular}$\longrightarrow$ & Lack of academic motivation (19) \\
Poor test taking skills (19) \\
Not attending classes (17) \\
Setting priorities (17) \\
Inadequate balance between other activities and class \\
work (16) \\
Poor concentration (13) \\
Difficulty in adjusting to a college routine (12) \\
Lack of interest / boredom (11) \\
Lack of career direction (10) \\
Poor reading skills (9)
\end{tabular}


TABLE 4

\section{Factors Selected by Males and Females in Pre-Business and Economics}

\begin{tabular}{|l|c|c|}
\hline \multicolumn{1}{|c|}{ FACTORS } & MALE RANK & FEMALE RANK \\
\hline Lack of career direction $(\mathrm{H})$ & 1 & Not Selected \\
\hline $\begin{array}{l}\text { Difficulty in adjusting to a } \\
\text { college routine(L) }\end{array}$ & 1 & 4 \\
\hline $\begin{array}{l}\text { Inadequate balance between other } \\
\text { activities and class work(A) }\end{array}$ & 3 & 8 \\
\hline Poor test-taking skills(C) & 3 & 1 \\
\hline Lack of academic motivation(G) & 5 & 5 \\
\hline Setting priorities(M) & 5 & 9 \\
\hline Not attending classes(K) & 7 & 1 \\
\hline Poor concentration(R) $(\mathrm{R})$ & 7 & 7 \\
\hline Lack of interest/boredom(X) & 9 & 5 \\
\hline Too much stress(I) & 9 & 5 \\
\hline Money Management $(\mathrm{J})$ & Not Selected & \\
\hline
\end{tabular}

\begin{tabular}{|c|c|}
\hline & $\begin{array}{l}\text { Difficulty in adjusting to college routine }(\mathrm{L}) 15 \\
\text { Inadequate balance between other activities and class work (A)13 }\end{array}$ \\
\hline \multirow{6}{*}{$\begin{array}{c}\text { MALE } \\
\underline{n}=24 \\
\%=64.8 \%\end{array}$} & Lack of academic motivation (G)12 \\
\hline & Setting priorities $(M) 12$ \\
\hline & Lack of career direction $(\mathrm{H}) 15$ \\
\hline & Not attending classes $(\mathbf{K}) 9$ \\
\hline & Poor concentration (R)9 \\
\hline & Too much stress (I) 7 \\
\hline
\end{tabular}

\begin{tabular}{|c|c|}
\hline & $\begin{array}{l}\text { Inadequate balance between other activities and class work (A)7 } \\
\text { Lack of academic motivation }(G) 7\end{array}$ \\
\hline \multirow{6}{*}{$\begin{array}{c}\text { FEMALE } \\
\qquad \begin{array}{c}n=13 \\
\%=35.1 \%\end{array}\end{array}$} & Poor concentration $(\mathbf{R}) 7$ \\
\hline & Difficulty in adjusting to college routine (L)5 \\
\hline & Too much stress (I)4 \\
\hline & Money Management (J)4 \\
\hline & Setting priorities (IM)4 \\
\hline & \\
\hline
\end{tabular}


TABLE 5

\section{Factors Selected by Males and Females in Pre-Biology}

\begin{tabular}{|l|c|c|}
\hline FACTOR & MALE RANK & FEMALE RANK \\
\hline $\begin{array}{l}\text { Inadequate balance between other } \\
\text { activities and class work(A) }\end{array}$ & 1 & 6 \\
\hline Poor test-taking skills(C) & 3 & 6 \\
\hline Lack of academic motivation(G) & 3 & 6 \\
\hline Not attending classes(K) & 3 & NOT SELECTED \\
\hline Difficulty in adjusting to a college & & 3 \\
routine(L) & 3 & 6 \\
\hline Poor concentration(R) & 3 & 1 \\
\hline Lack of interest/boredom(X) & 8 & 3 \\
\hline Setting priorities(M) & 8 & 3 \\
\hline Poor reading skills(D) & 8 & \\
\hline Experiencing test anxiety(F) & & \\
\hline
\end{tabular}

\begin{tabular}{|c|c|}
\hline & $\begin{array}{l}\text { Inadequate balance between other activities and class work (A)3 } \\
\text { Experiencing test anxiety }(\mathrm{F}) 2\end{array}$ \\
\hline \multirow{4}{*}{$\begin{array}{c}\text { MALE } \\
\underline{n}=5 \\
\%=41.6 \%\end{array}$} & Poor test-taking skills (D)2 \\
\hline & Lack of interest / boredom (X)1 \\
\hline & Setting priorities $(\mathbf{M}) 1$ \\
\hline & $\begin{array}{l}\text { Poor reading skills }(\mathrm{D}) 1 \\
\text { Experiencing test anxiety }(\mathrm{F}) 1\end{array}$ \\
\hline
\end{tabular}

\begin{tabular}{|c|}
\hline $\begin{array}{c}\text { FEMALE } \\
\underline{n}=7 \\
\%=58.3 \%\end{array}$ \\
\hline \\
\hline
\end{tabular}

Inadequate balance between other activities and class work (A)4 Setting priorities $(M) 4$

Poor concentration (R)3

Poor reading skills (D)3

Experiencing test anxiety (F)3

Lack of academic motivation( G)3

Poor test-taking skills (D)3

Difficulty in adjusting to college routine $(\mathrm{L}) 3$

Lack of interest/boredom (X)3 
TABLE 6

\section{Factors Selected by Males and Females in Pre-Psychology}

\begin{tabular}{|l|c|c|}
\hline \multicolumn{1}{|c|}{ FACTORS } & MALE RANK & FEMALE RANK \\
\hline Poor test-taking skills(C) $(1$ & 2 \\
\hline Experiencing test anxiety(F) & 2 & 6 \\
\hline Not attending classes(K) & 2 & 6 \\
\hline Too much stress(I) & 2 & 2 \\
\hline $\begin{array}{l}\text { Difficulty in adjusting to a college } \\
\text { routine(L) }\end{array}$ & 2 & 6 \\
\hline Poor reading skills(R) & 6 & 6 \\
\hline Lack of interest/boredom $(\mathrm{X})$ & 6 & 6 \\
\hline Other(Y) & 6 & NOT SELECTED \\
\hline $\begin{array}{l}\text { Inadequate balance between other } \\
\text { activities and class work }(\mathrm{A})\end{array}$ & NOT SELECTED & 2 \\
\hline Lack of academic motivation(G) $(\mathrm{G})$ & 9 & 2 \\
\hline Setting priorities $(M)$ & NOT SELECTED & \\
\hline
\end{tabular}

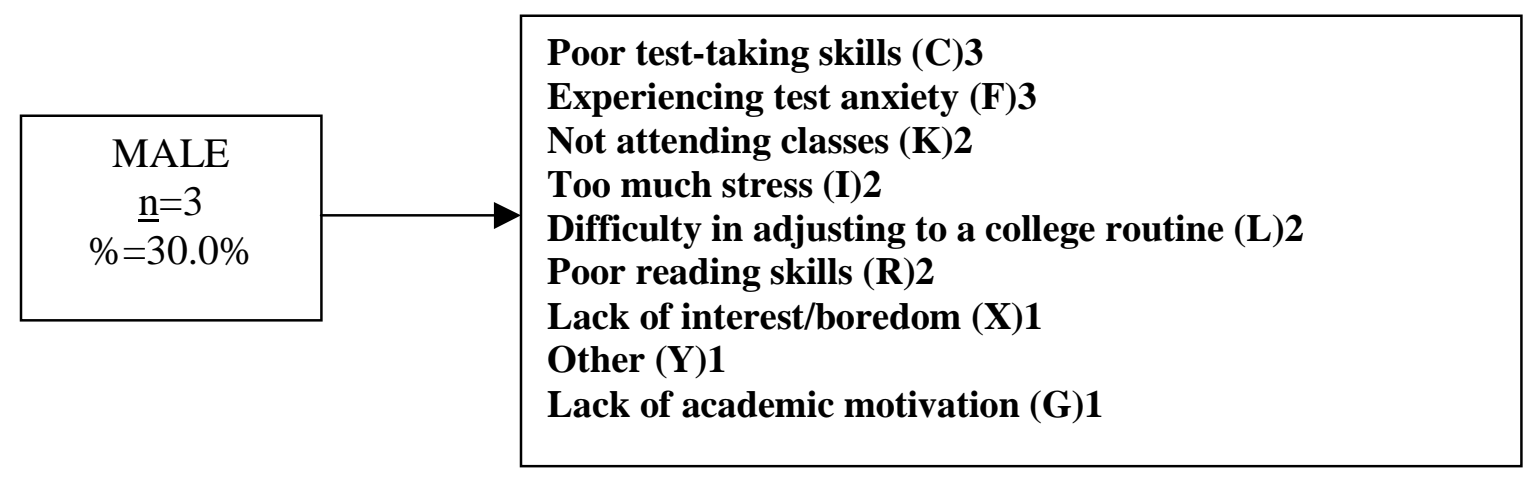

\begin{tabular}{|c|c|}
\hline & Inadequate balance between other activities and class work (A)4 \\
\hline & Poor test-taking skills (C)3 \\
\hline \multirow{8}{*}{$\begin{array}{c}\text { FEMALE } \\
\qquad \begin{array}{l}\underline{\mathrm{n}}=7 \\
\%=70.0 \%\end{array}\end{array}$} & Lack of academic motivation (G)3 \\
\hline & Setting priorities $(\mathbf{M}) 3$ \\
\hline & Too much stress (I)3 \\
\hline & Experiencing test anxiety F)2 \\
\hline & Not attending classes $(\mathrm{K}) 2$ \\
\hline & Poor reading skills $(\mathbf{R}) 2$ \\
\hline & Difficulty in adjusting to a college routine $(\mathrm{L}) 2$ \\
\hline & Lack of interest/boredom (X)2 \\
\hline
\end{tabular}




\section{CHAPTER FIVE}

\section{Discussion}

The primary purpose of this study was to examine the factors leading to a student being placed on academic probation. This study was limited to data collected from January to March of 2000 through the undergraduate academic advising center at West Virginia University. All students placed on academic probation in the spring of 2000 were strongly encouraged to complete the survey, although it was not a requirement. Of the 386 students advised at the academic advising center, 172 (44.3\%) of the students placed on probation responded to the survey.

Although difficulty in decision making was not a primary factor in a student's poor performance for this survey, it still remains a main factor examined by universities for freshmen placed in a new environment that is less structured (Wratcher, 1991). Both males and females viewed lack of interest/boredom, poor reading skills, and problems with roommates to be equal in their frequency of their response. Out of the 25 factors that could have been selected, the students actually selected two or more. This suggests that the problem cannot be solved by using one factor; it is a combination of factors, one perhaps more contributory than another, or perhaps four or five equally contributing. Due to the small cells, the data set was too random to draw a clear conclusion.

Past research has shown time management, test-taking skills, note-taking and critical thinking have been major components to a student's academic success (Wratcher, 1991). Others would argue that having a declared major, individualized attention from the faculty, and frequent meetings with an advisor leads to academic success (Koestner \& 
Senecal, 1995). This survey showed that for males inadequate balance of time was the primary factor for their poor performance and supports the finding in the literature of a necessity for time management among college males. For females, lack of academic motivation was the number one reason given for their probation. This was a surprise due to the research conducted by Hickman, Toews, and Andrews (2001) that found, women tend to be nurtured more and supported early on in their school careers, which would indicate an environment to facilitate academic motivation.

The selections of factors the students choose as the cause of their poor performance were somewhat surprising. For males in general studies their selection of priorities, adjustment to college, and balancing of time could be a reflection of the pressures placed on college males to have strong social interactions with peers. However, for the females in general studies, their selection of poor test-taking and lack of motivation being the leading factors possibly indicates a lack of academic preparation rather than social pressures. Many of the factors selected within this group indicated possible inadequate preparation prior to entering a college environment.

Selection of poor career direction and difficulty adjusting to college life by rebusiness and economics males indicates a possible need for more contact with a faculty member or advisor for guidance. Surprisingly females in pre- business and economics did not select lack of career direction. Perhaps they already have a good sense of what they want to pursue academically. They did select not attending classes as one of their leading predictors of their probation, and this suggests that attending class to obtain lecture notes is half of the battle to succeed academically. 
The largest difference to discuss among pre-biology majors was the selection of not attending classes by males and not by females. Many of the science courses require laboratory classes to supplement the lecture, which requires attendance to satisfactorily complete the course. For the pre-psychology group they had the greatest variation within the group of the selection of factors contributing to their probation. These differences within the group could possibly be attributed to varying study habits and time management issues between the genders. There was also some variation among the choices of factors selected between the different majors. These differences can possibly be due to the differences in demands' the majors place on the student.

Since misinterpretations or misunderstandings of the instructions could jeopardize the results of the study, each advisor was instructed to assist the student in the completion of the survey. The instrument used appeared to be valid for the purposes of this study. The students who participated did not appear to have any problem reporting for this study. Most criticisms of questionnaires are related not to their use but to their misuse. Carelessly constructed questionnaires have unfortunately been administered too often. The accuracy of this investigation depended upon the participants' responses to the questionnaire. The participants must be able to provide the desired information and be willing to provide it to the researcher (Airasian \& Gay, 2000). Individuals that possess desired information but are not sufficiently interested, or for whom the topic under study has limited meaning, are not likely to respond at all.

As far as implications for identifying leading factors contributing to a students academic probation, these results provide additional support for the necessity of 
universities to use an instrument to examine a student's academic progress. It is important as educators to attempt to clearly ascertain what factors contribute to academic failure in their college career. For many researchers, a student's high school achievement and standardized testing scores are the predictors for success (Braunstein \& McGrath, 1987). For other researchers, a student's time management ability and social integration into a university environment are the measures for academic progress (Tinto, 1975, 1987). Whatever the correct indicator may be, it is evident that an accurate and reliable method to predict a student's probability to succeed has yet to be determined.

What does this mean for advisors at universities? Concentrating on the top ten factors known to be problem areas for freshmen is the focal point. Stressing the necessity for a time management course to be taken within the first semester of college and having a schedule that fits the time and needs of the student would be viable for student success. Also for the advisor to review with the student what the requirements are for their major and how these requirements correspond with the student's interests. The advisor/student review needs to be done before they take more classes that are not interesting to them and have difficulty succeeding in. Perrine (2001) discussed the necessity for frequent and rewarding contact between faculty/staff and students for student progress and social integration.

\section{Future Research}

To further investigate the factors leading to a student's poor performance, a larger sample should be used to check for variation or relationships among the factors, gender, and majors. The slight differences between males and females in choice of factors 
should be studied at other universities or institutions to measure for consistency. A comparison of non-probationary student's selections of factors to the probationary students' selections to test for differences would be equally important. Tinto (1987) found a possibility of specific traits of personality which tend to describe real differences between the patterns of response of persisters and those who fail or eventually leave. Finally, future research needs to be conducted in a longitudinal study to track students through their graduation or possible early departure from the university. A study that looks at student's balance between study habits and other activities, their grade point averages, and their progress in completing the curriculum required for the major they are attempting to receive. More research should be conducted to ascertain if procrastination does have an affect on academic performance and academic motivation in female college students. 


\section{References}

ACT, Inc., (2000, February). College dropout rate improves, but graduation rate falls. ACTNEWSROOM, February 16, 2001. Retrieved from http://www.act.org/news/releases/2000/02-16-00.html

Airasian, P., \& Gay, L. R. (2000). Educational research: Competencies for analysis and application. New Jersey: Prentice-Hall, Inc.

Astin, A. W., Hemond, M. K., \& Richardson, G. T. (1982). The American freshman. National norms for fall 1982. Los Angeles: Graduate School of Education, University of California.

Berry, T. R., Pike, G. R., \& Schroeder, C. C. (1997). Enhancing the educational impact of residence halls: The relationship between residential learning communities and first-year college experiences and persistence. Journal of College Student Development, 38, 609-621.

Biller, H. B. (1993). Fathers and families. Westport, CT: Auburn House.

Braunstein, A., \& McGrath, M. (1997). The prediction of freshman attrition: An examination of the importance of certain demographic, academic, financial, and social factors. College Student Journal, 31, 396-408.

Brazziel, M. E. (1982). The college freshman adjustment scale. Journal of National Association of Woman Deans, Administrators, \& Counselors, 45, 27-33.

Dey, E. L, Astin, A. W., \& Korn, W. S. (1991). The American freshman: Twenty-five year trends. California: Higher Education Research Institute, Graduate School of Education. University of California. 
Hickman G. P., Toews, M. L., \& Andrews, D. W. (2001). The different influence of authoritative parenting on the initial adjustment of male and female traditional college freshmen. Journal of The First-Year Experience, 13, 23-46.

Karabenick, S. A., \& Knapp, J. R. (1988). Incidence of formal and informal academic help-seeking in higher education. Journal of College Student Personnel, 29, 223-227.

Kenny, M. E. (1987). Family ties and leaving home for college: Recent findings and implications. Journal of College Student Personnel, 28, 438-442.

Koestner, R., \& Senecal, C. (1995). Self-regulation \& academic procrastination. Journal of Social Psychology, 135, 607-619.

Pascarella, E. T., \& Terenzini, P. T. (1979). Interaction effects in Spady's and Tinto's conceptual model of college dropout. Sociology of Education, 52, 197-210.

Perrine, R. M. (2001). College stress and persistence as a function of attachment and support. Journal of the First-Year Experience, 13, 7-22.

Solomon, L. J., \& Rothblum, E. D. (1984). Academic procrastination: Frequency and cognitive-behavioral correlates. Journal of Counseling Psychology, 31, 503-509.

Tinto, V. (1975). Dropout from higher education: A theoretical synthesis of research. Review of Educational Research, 45, 89-125.

Tinto, V. (1987). Leaving college: Rethinking the causes and cures of student attrition. Chicago: University of Chicago Press.

Upcraft, M. L., \& Gardner, J. N. (1989). The freshman year experience: 
Helping students survive and succeed in college. California: Jossey-Bass Inc., Publishers.

Vallerand, R. J., \& Bissonnette, R. (1992). On the predictive effects of intrinsic, extrinsic, and amotivational styles on behavior: A prospective study. of Personality, 60, 599-620.

Wratcher, M. A. (1991). Helping freshman to maximize their learning potential. Journal of College Student Development, 32, 380-382.

Wratcher, M. A. (1991). Freshman academic adjustment at a competitive university. College Student Journal, 25, 170-177. 
Appendix A

Distribution of Majors

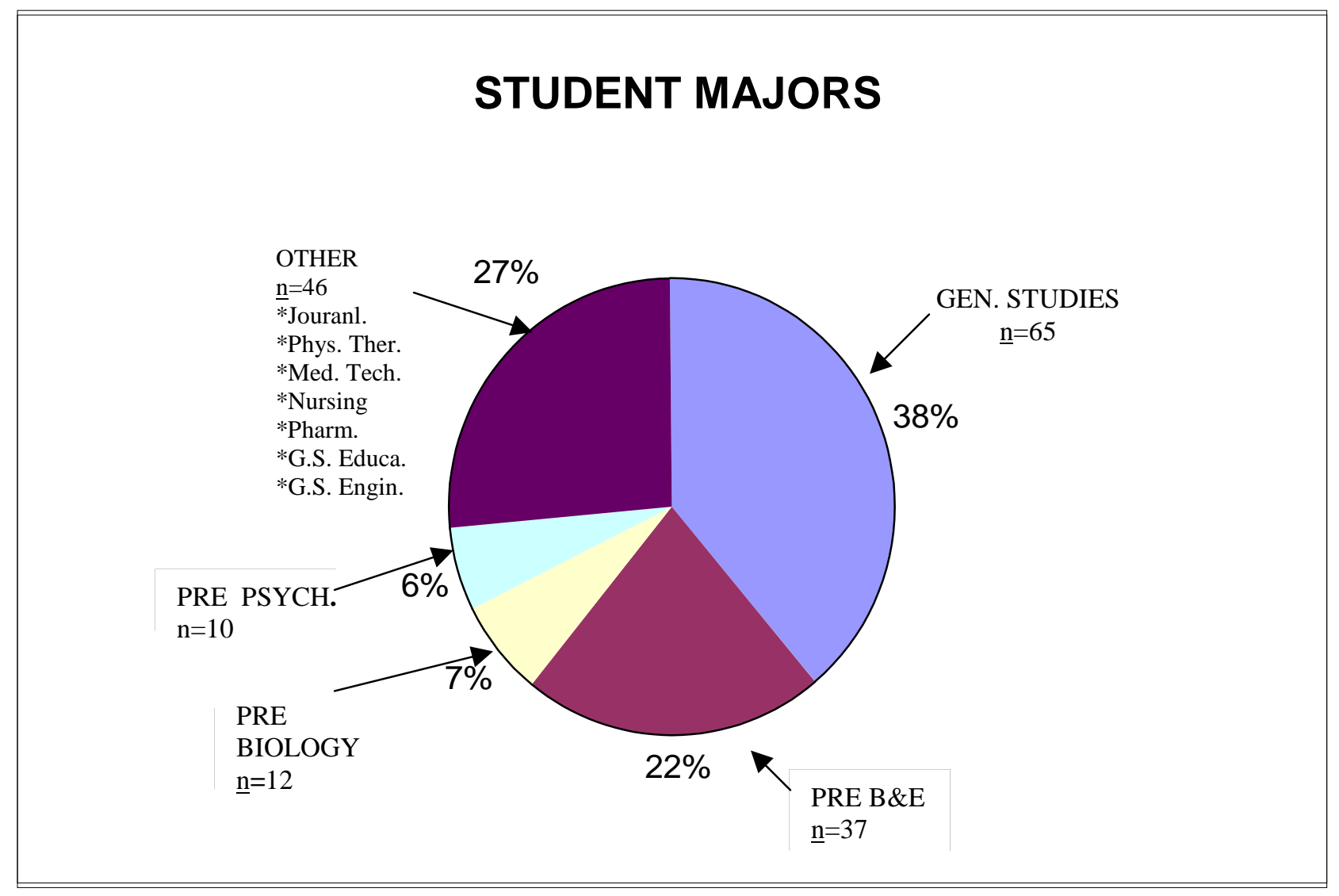




\section{Appendix B}

Factors Contributing To Poor Academic Performance

Name:

Social Security Number:

Date:

Please check below:

Student is on academic probation:

Student has received 3-4 midterm reports:

Please indicate below which factors have contributed to your poor academic performance:

$A=$ Inadequate balance between other activities and classwork

$\mathrm{B}=$ Poor note-taking skills

$\mathrm{C}=$ Poor test-taking skills

$\mathrm{D}=$ Poor reading skills

$\mathrm{E}=$ Poor writing skills

$\mathrm{F}=$ Experiencing test anxiety

$\mathrm{G}=$ Lack of academic motivation

$\mathrm{H}=$ Lack of career direction

$\mathrm{I}=$ Too much stress

$\mathrm{J}=$ Money management

$\mathrm{K}=$ Not attending class

$\mathrm{L}=$ Difficulty in adjusting to a college routine

$\mathrm{M}=$ Setting priorities

$\mathrm{N}=$ Problems with roommate

$\mathrm{O}=$ Interpersonal relationships

$\mathrm{P}=$ Health

$\mathrm{Q}=$ Difficulty in decision making

$\mathrm{R}=$ Poor concentration

$\mathrm{S}=$ Loneliness

$\mathrm{T}=$ Difficulty learning specific course material

$\mathrm{U}=$ Depression

$\mathrm{V}=$ Use of alcohol and/or drugs

$\mathrm{W}=$ Inadequate family and friend support

$\mathrm{X}=$ Lack of interest/boredom

$\mathrm{Y}=$ Other 


\section{Appendix C \\ List of Factors for "Other” Category}

- Went to wrong location

- Class moved too fast, hard to keep up

- Laziness

- Having to move in middle of semester

- Death in family

- Work

- Joining a sorority/fraternity

- Being out of school to long (5 years)

- Late starting the semester

- Placed on medication for ADD (attention deficit disorder)

- Financial aid late/unable to purchase books

- Homesickness

- Oversleeping

- Difficulty with professor

- Family moved

- Classes too early 
Appendix D

\section{List of Factors for Difficulty Learning Specific Course Material}

Biology 1=General Biology

Biology 15=Priniciples of Biology

Chemistry $10=$ Introduction to Chemistry

Chemistry $15=$ Fundamentals of Chemistry

Computer Science 15=Introduction to Computer Science

Geology 1=Planet Earth

Math 4=Plane Trigonometry

Math 15=Calculus

Math 128=Introduction to Calculus

Music 30=Introduction to Music

Philosophy 2=Historical Introduction to Philosophy

Political Science 2=Introduction to the American Government

Psychology 1=Introduction to Psychology

Spanish 1=Elementary Spanish

*The course numbers are based on West Virginia University course codes. 
Appendix E

Table 7

Results of Chi-square analysis

Descriptive Statistics

\begin{tabular}{|l|r|r|r|r|r|}
\hline & $\mathrm{N}$ & Mean & $\begin{array}{c}\text { Std. } \\
\text { Deviation }\end{array}$ & Minimum & Maximum \\
\hline GENDER & 172 & 1.4884 & .5013 & 1.00 & 2.00 \\
Major Code & 172 & 5.0349 & 5.3046 & 1.00 & 18.00 \\
\hline
\end{tabular}

GENDER

\begin{tabular}{|l|r|r|r|}
\hline & \multicolumn{2}{|c|}{ Observed } & \\
$\mathrm{N}$ & Expected N & Residual \\
\hline Male & 88 & 86.0 & 2.0 \\
Female & 84 & 86.0 & -2.0 \\
Total & 172 & & \\
\hline
\end{tabular}

MAJOR CODE

\begin{tabular}{|l|r|r|r|}
\hline & $\begin{array}{r}\text { Observed } \\
\mathrm{N}\end{array}$ & Expected N & Residual \\
\hline general stud. & 65 & 9.6 & 55.4 \\
pre b\&e & 37 & 9.6 & 27.4 \\
pharmacy & 4 & 9.6 & -5.6 \\
pre english & 1 & 9.6 & -8.6 \\
g.s.education & 5 & 9.6 & -4.6 \\
g.s. engineer & 6 & 9.6 & -3.6 \\
pre poli. sci & 4 & 9.6 & -5.6 \\
pre psych & 10 & 9.6 & .4 \\
pre nursing & 4 & 9.6 & -5.6 \\
pre comm. stud. & 1 & 9.6 & -8.6 \\
pre bio. & 12 & 9.6 & 2.4 \\
pre foreign\&b\&e & 1 & 9.6 & -8.6 \\
pre hist. & 2 & 9.6 & -7.6 \\
pre phys. ther. & 6 & 9.6 & -3.6 \\
pre for. lang. & 1 & 9.6 & -8.6 \\
pre occ. ther. & 2 & 9.6 & -7.6 \\
pre med. tech. & 3 & 9.6 & -6.6 \\
pre journ. & 8 & 9.6 & -1.6 \\
Total & 172 & & \\
\hline
\end{tabular}




\section{Appendix E}

\section{Table 7}

\section{Results of Chi-square analysis} continued

\section{Test Statistics}

\begin{tabular}{|l|r|r|}
\hline & GENDER & \multicolumn{1}{c|}{$\begin{array}{c}\text { Major } \\
\text { Code }\end{array}$} \\
\hline Chi-Square $^{\text {a, }}$ & .093 & 463.023 \\
df & 1 & 17 \\
Asymp. Sig. & .760 & .000 \\
\hline
\end{tabular}

a. 0 cells $(.0 \%)$ have expected frequencies less than 5. The minimum expected cell frequency is 86.0.

b. 0 cells $(.0 \%)$ have expected frequencies less than 5. The minimum expected cell frequency is 9.6 .

\begin{tabular}{|c|c|c|c|}
\hline \multicolumn{4}{|c|}{ Chi-Square Tests } \\
\hline & Value & $\mathrm{df}$ & $\begin{array}{l}\text { Asymp. } \\
\text { Sig. } \\
\text { (2-sided) }\end{array}$ \\
\hline Pearson Chi-Square & $23.744^{a}$ & 17 & .127 \\
\hline Likelihood Ratio & 29.052 & 17 & .034 \\
\hline $\begin{array}{l}\text { Linear-by-Linear } \\
\text { Association }\end{array}$ & 2.693 & 1 & .101 \\
\hline $\mathrm{N}$ of Valid Cases & 172 & & \\
\hline
\end{tabular}

a. 29 cells $(80.6 \%)$ have expected count less than 5 . The minimum expected count is .49 . 
Appendix F

\section{Crosstabulation of Gender and Major Code}

MAJORCOD * GENDER Crosstabulation

\begin{tabular}{|c|c|c|c|c|c|}
\hline & & & GEI & & \\
\hline & & & Male & Female & Total \\
\hline MAJORCOD & General Studies & Count & 36 & 29 & 65 \\
\hline & & Expected Count & 33.3 & 31.7 & 65.0 \\
\hline & pre b\&e & Count & 24 & 13 & $3 \bar{i}$ \\
\hline & & Expected Count & 18.9 & 18.1 & $37 . C$ \\
\hline & pre pharmacy & Count & 1 & 3 & 4 \\
\hline & & Expected Count & 2.0 & 2.0 & 4.C \\
\hline & pre english & Count & 1 & 0 & 1 \\
\hline & & Expected Count & .5 & .5 & 1.C \\
\hline & g.s.education & Count & 2 & 3 & 5 \\
\hline & & Expected Count & 2.6 & 2.4 & 5.C \\
\hline & g.s. engineer & Count & 4 & 2 & $\epsilon$ \\
\hline & & Expected Count & 3.1 & 2.9 & 6.C \\
\hline & pre poli. sci & Count & 1 & 3 & 4 \\
\hline & & Expected Count & 2.0 & 2.0 & 4. C \\
\hline & pre psych & Count & 3 & 7 & 10 \\
\hline & & Expected Count & 5.1 & 4.9 & $10 . C$ \\
\hline & pre nursing & Count & 0 & 4 & 4 \\
\hline & & Expected Count & 2.0 & 2.0 & 4.C \\
\hline & pre comm. stud. & Count & 0 & 1 & 1 \\
\hline & & Expected Count & .5 & .5 & 1.C \\
\hline & pre bio. & Count & 5 & 7 & $12:$ \\
\hline & & Expected Count & 6.1 & 5.9 & $12 . C$ \\
\hline & pre business & Count & 1 & 0 & 1 \\
\hline & and foreign & Expected Count & .5 & .5 & 1.C \\
\hline & pre hist. & Count & 1 & 1 & 2 \\
\hline & & Expected Count & 1.0 & 1.0 & 2.C \\
\hline & pre phys. ther. & Count & 3 & 3 & $\epsilon$ \\
\hline & & Expected Count & 3.1 & 2.9 & 6.C \\
\hline & pre for. lang. & Count & 0 & 1 & 1 \\
\hline & & Expected Count & .5 & .5 & $1 . C$ \\
\hline & pre occ. ther. & Count & 0 & 2 & 2 \\
\hline & & Expected Count & 1.0 & 1.0 & 2.C \\
\hline & pre med. tech. & Count & 0 & 3 & $\Xi$ \\
\hline & & Expected Count & 1.5 & 1.5 & 3. $C$ \\
\hline & pre journ. & Count & 6 & 2 & $\varepsilon$ \\
\hline & & Expected Count & 4.1 & 3.9 & 8.C \\
\hline Total & & Count & 88 & 84 & 172 \\
\hline & & Expected Count & 88.0 & 84.0 & 172.0 \\
\hline
\end{tabular}

*MAJORCOD refers to the students majors coded by West Virginia University. 